\title{
STRATEGI MENINGKATKAN QUALITY ASSURANCE PADA SATUAN PENGAWASAN INTERNAL PERUM JASA TIRTA II JATILUHUR
}

\author{
STRATEGY FOR IMPROVING QUALITY ASSURANCE \\ ON THE INTERNAL AUDIT UNIT OF PERUM JASA TIRTA II JATILUHUR
}

\author{
Budi Hanta $^{*}$, Dedi Budiman Hakim**), dan Agus Maulana*) \\ *) Sekolah Bisnis, IPB University \\ Jl. Padjajaran, Bogor, Indonesia 16151, Indonesia \\ **) Departemen Ilmu Ekonomi, Fakultas Ekonomi dan Manajemen, IPB University \\ Jl. Agatis Kampus IPB Darmaga, Bogor 16680, Indonesia
}

\begin{abstract}
This study aimed to formulate alternative strategies and determine priority strategies to improve internal audit quality assurance. This was a case study on Jasatirta II Internal Audit by evaluating the level of quality assurance in 2017. The analysis used was SWOT, EI, Fishbone and Analytic Network Process (ANP). The purposive judgment samples included Auditors, Board of Directors and Commissioners, Management, and Academics. The results showed that problems in quality assurance from 6 aspects of the Internal Auditor Capability Model (IA-CM) were: from roles and services aspects: less maximum audit service (53.10\%) and other services (60\%), from governance structure aspects: inadequate infrastructure $(67.70 \%)$, from organization's cultural relationship aspects: work culture fulfillment (51.70\%), while aspects of HR management, professional practice, as well as performance management and accountability were still within reasonable limits (above 60\%). The SWOT analysis in quadrant I and Matrix I/E in cell IV showed that the position of the organization grows, develops, and strong. Therefore, the fishbone diagram raised 3 alternative strategies to improve IA quality assurance: strengthening the Board of Directors and Commissioners, strengthening infrastructure through IT, and focusing on strengthening independent HR. Determination of the strategy chosen through ANP was the strengthening of support from BOD/BOC (40.98\%).
\end{abstract}

Keywords: ANP, fishbone analisys, internal audit, internal/extenal analisys, quality assurance, SWOT Analisys

\begin{abstract}
Abstrak: Penelitian ini bertujuan merumuskan strategi alternatif dan menetukan prioritas strategi meningkatkan penjaminan kualitas audit internal (AI). Ruang lingkup penelitian adalah studi kasus pada AI Perum Jasa Tirta II dengan mengevalusi tingkat jaminan mutu tahun 2017. Analisis yang digunakan adalah Analisis SWOT, Analisis EI, Analisis fishbone dan Analytic Network Process (ANP). Teknik pengambilan sampel purposive judgement sampling meliputi Auditor, Dewan Direksi, Dewan Komisaris, Manajemen serta Akademisi. Hasil penelitian menunjukkan bahwa masalah dalam jaminan kualitas dari 6 aspek Model Kemampuan Auditor Internal (IA-CM) adalah dari aspek peran dan layanan: layanan audit $(53,10 \%)$ dan layanan lain (60\%) kurang maksimal, dari tata kelola aspek struktur: infrastruktur yang tidak memadai $(67,70 \%)$, dari aspek hubungan budaya organisasi: pemenuhan budaya kerja $(51,70 \%)$, sedangkan aspek manajemen SDM, praktik profesional, serta manajemen kinerja dan akuntabilitas masih dalam batas wajar (di atas 60\%). Dengan Analisa SWOT menunjukkan posisi organisasi pada kuadran I dan Matriks I/E pada sel IV yang berarti bahwa posisi organisasi tumbuh, kuat dan berkembang. Berdasarkan hal tersebut maka diagram fishbone memunculkan 3 stratategi alternatif yang mengarah pada strategi meningkatkan quality assurance AI, yaitu Penguatan Dewan Direksi dan Dewan Komisaris, Penguatan infrastruktur dengan IT, dan Memfokuskan penguatan SDM yang mandiri. Penentuan stategi yang dipilih memalui ANP yakni Pengutan dukungan dari BOD/BOC (40,98\%)
\end{abstract}

Kata kunci: ANP, audit internal, analisis fishbone, analisis internal/eksternal, Analisis SWOT, Quality Assurance

\footnotetext{
${ }^{1}$ Corresponding author:

Email: budi.ppak@gmail.com
} 


\section{PENDAHULUAN}

Peraturan Menteri Badan Usaha Milik Negara (BUMN) Nomor: PER-01/MBU/2011 menjelaskan bahwa Satuan Pengawasan Internal (SPI) merupakan organ pendukung dalam tata kelola perusahaan yang dibentuk oleh Direksi dengan fungsi mengevaluasi efektivitas pelaksanaan pengendalian internal, manajemen risiko, tata kelola perusahaan sesuai dengan peraturan perundang-undangan dan melakukan pemeriksaan serta penilaian atas efisiensi dan efektivitas proses bisnis perusahaan. Tujuan utama audit internal adalah untuk membantu organisasi mencapai tujuannya (AAI, 2016). Dalam melakukan fungsi utama Perum Jasa Tirta II (PJT II) Jatiluhur, diperlukannya sebuah aktivitas yang independen, penjaminan/keyakinan yang tidak berfihak (objective assurance), dan konsultansi yang dirancang untuk memberikan nilai tambah dan mengembangkan kegiatan operasi (IIA, 2017) hal tersebut dapat dicerminkan melalui fungsi audit internal yang membantu organisasi mewujudkan tujuan dan sasarannya melalui pendekatan yang sistematis dan teratur dengan mengevaluasi efektivitas proses manajemen risiko, proses pengendalian dan proses tata kelola (Sawyer, 1996).

Tabel 1 menggambarkan bahwa jaminan mutu SPI telah diterapkan di berbagai institusi pemerintah maupun BUMN/BUMD di banyak sektor. Pada sektor Perbankan sudah diukurkan tingkat pemenuhan Kapabilitas SPI dengan model pengukuran IACM di Level 4 (Managed) dimana level ini dengan karakteristik Auditor Internal telah mengintegrasikan informasi dari berbagai organisasi untuk peningkatan tata kelola dan manajemen risiko, dan pada sektor yang lainnya/non perbankan sudah diukurkan dengan model IA-CM di Level 3 (Integrated), level ini dengan karakteristik manajemen Internal Audit dan praktik profesionalnya telah ditetapkan secara seragam (IIA, 2009).

Pada Gambar 1 terdapat empat masalah utama yang terjadi di SPI PJT II yaitu rendahnya pemenuhan aspek Budaya Kerja $(51,70 \%)$, kurang maksimal dalam pemberian jasa audit $(53,10 \%)$, kurang maksimalnya pemberian jasa lainnya/non audit $(60 \%)$, dan kurangnya infrastruktur yang memadai $(67,70 \%)$, dimana keempat hal tersebut merupakan hal yang mendasar bagi unit SPI dalam memberikan jaminan kualitasnya.
Tujuan dari penelitian ini yakni, mengidentifikasi dan mengevaluasi faktor-faktor internal dan eksternal yang mempengaruhi hasil penilaian quality assurance pada SPI PJT II yang tidak obtimal, merumuskan alternatif strategi dan menentukan prioritas strategi peningkatan quality assurance pada SPI PJT II.

Tabel 1. Tingkat Pemenuhan Capabilitas AI

\begin{tabular}{lcc}
\hline Nama Instansi & Level IACM & $\begin{array}{c}\text { Tingkat } \\
\text { Pemenuhan }\end{array}$ \\
\hline Bank Mandiri & 4 & $100,00 \%$ \\
Bank KalSel & 4 & $90,13 \%$ \\
BRI) & 4 & $85,00 \%$ \\
Petrokimia G & 3 & $100,00 \%$ \\
Kemen-BUMN & 3 & $94,60 \%$ \\
BPK & 3 & $82,37 \%$ \\
Bio Farma & 3 & $79,50 \%$ \\
Brantas Ab & 3 & $72,07 \%$ \\
PJT II & 3 & $71,56 \%$ \\
Askrindo & 3 & $70,00 \%$ \\
BPJS Kesehatan & 3 & $66,40 \%$ \\
Wijaya Karya & 3 & $64,00 \%$ \\
\hline
\end{tabular}

Sumber: Kuesioner tingkat pemenuhan capabilitas SPI BUMN tahun 2016-2018 (diolah)

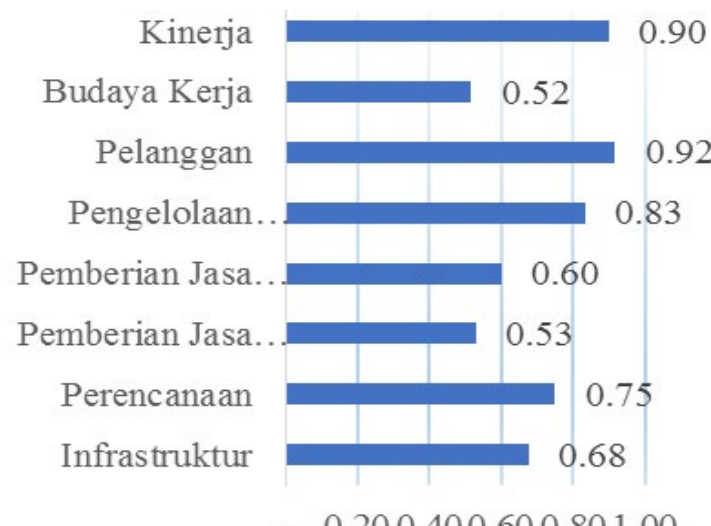

Gambar 1. Grafik tingkat quality assurance Tahun 2016 SPI PJT I

\section{METODE PENELITIAN}

Penelitian ini merupakan penelitian studi kasus. Menurut Rahardjo dan Gudnanto (2011) penelitian studi kasus diterapkan untuk memahami objek penelitian secara lebih mendalam dengan dipraktekkan secara integratif dan komprehensif. Melalui studi kasus diharapkan kebutuhan penelitian mendapatkan pemahaman mendalam terkait penerapan quality assurance pada Satuan Pengawas Internal (SPI) PJT 
II sehingga mampu menyusun rekomendasi strategi yang relevan. Penelitian dilakukan di Kantor Pusat PJT II. Waktu pengumpulan data dilakukan di bulan Februari - Juni 2019. Jenis data dalam penelitian ini terdiri dari data primer dan data sekunder. Data primer diperoleh melalui pengisian kuesioner dan wawancara mendalam dengan para ahli dan praktisi untuk memahami masalah secara komprehensif. Responden dipilih secara purposive judgement sampling sebanyak 13 orang terdiri dari 1 orang Direksi, 1 anggota Dewan Pengawas sekaligus Ketua Komite Audit, 9 orang Auditor Internal, dan 1 orang Akademisi. Data sekunder yang diperlukan dalam penelitian ini adalah data yang didapatkan dari pengumpulan referensi dari berbagai buku dan laporan terkait kegiatan audit dan contoh penulisan lainnya yang berkaitan dengan masalah penelitian serta menunjang landasan teori yang menjadi pedoman dalam pembahasan masalah penelitian seperti Laporan Qulaity Assurance SPI.

Metode penelitian yang digunakan untuk mencapai setiap tujuan penelitian disajikan pada Tabel 2. Adapun Kerangka alur penelitian tersaji pada Gambar 2. Pada tahap terakhir ini, yaitu sintesis jaringan ANP menggunakan perangkat lunak Superdecisions. Output yang diharapkan yaitu untuk dapat menghasilkan hasil 'konsensus' ilmiah dengan cara geometrik melakukan kuantifikasi semua tanggapan responden. Kemudian dimasukkan kembali ke jaringan ANP dalam perangkat lunak Superdecisions untuk sintesis ulang (Abrista, 2018). Persamaan untuk menghitung mean geometris untuk menghitung rata-rata yang menunjukkan nilai tertentu (Ascarya, 2011) meliliki formula sebagai berikut:

$$
\begin{aligned}
G & =\sqrt[n]{x_{1} \times x_{2} \times \cdots \times x_{n}} \\
& =\sqrt[n]{\prod_{i=1}^{n} x_{i}}
\end{aligned}
$$

Keterangan: G (rata-rata ukur (geometric)); i (1,2, 3, n); Xi (nilai sample ke i); n (banyaknya sample).

\section{HASIL}

\section{Identifikasi Faktor Strategis}

Berdasarkan hasil identifikasi diperoleh faktor internal dan ekternal yang terdiri dari faktor kekuatan, kelemahan, peluang dan ancaman. Dari hasil evaluasi faktor strtategis internal dan eksternal didapatkanlah score tertimbang (bobot dikalikan rating masingmasing faktor strategis). Nilai total tertimbang adalah hasil penjumlahan dari score tertimbang. Total score tertimbang pada kekuatan (2,2623), Total score tertimbang pada kelemahan $(0,7531)$ (Tabel 3). Hasil penjumlah total tertimbang kekuatan dan total score tertimbang kelemahan merupakan total tertimbang faktor internal strategis yaitu senilai 3,0154. Sedangkan total tertimbang faktor eksternal strategis yaitu senilai 2,9345 yang merupakan penjumlahan dari total score tertimbang pada peluang $(2,0559)$ dengan total score tertimbang pada ancaman $(0,8786)$ (Tabel 4$)$. Hasil dari score tertimbang juga digambarkan pada sel tertentu dan memberntuk sebuah matriks Internal/eksternal (I/E) yang digunakan untuk mengetahui posisi organisasi berdasarkan tingkat respon terhadap faktor internal dan eksternal seperti nampak pada Gambar 3.

Tabel 2. Metode yang digunakan untuk menjawab tujuan

\begin{tabular}{lll}
\hline Tujuan Penelitian & Metode & Hasil \\
\hline $\begin{array}{l}\text { Identifikasi faktor intrenal dan } \\
\text { eksternal }\end{array}$ & Analisis deskriptif & Faktor internal eksternal \\
$\begin{array}{l}\text { Evaluasi faktor internal dan eksternal } \\
\text { Merumuskan alternatif strategi } \\
\text { generik }\end{array}$ & $\begin{array}{l}\text { Analisa EFI dan EFE serta SWOT } \\
\text { FishBone diagram }\end{array}$ & $\begin{array}{l}\text { Posisi organisasi } \\
\text { Membangun kriteria, subkriteria, elemen- } \\
\text { elemen dan mencari akar masalah untuk } \\
\text { pilihan alternatif } \\
\text { Menentukan prioritas strategi }\end{array}$ \\
& $\begin{array}{l}\text { Analitical Networking Process } \\
\text { (ANP) }\end{array}$ & Pilihan strategi prioritas \\
\hline
\end{tabular}


Hasil assessment quality assurance pada SPI PJT II belum optimal

Evaluasi faktor-faktor yang menyebabkan hasil penilaian tidak optimal

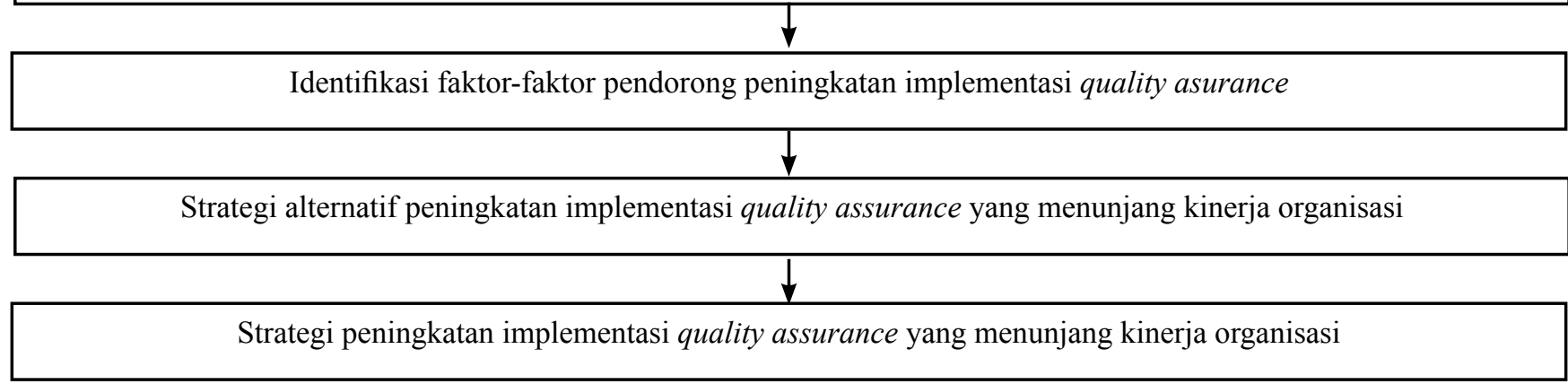

Gambar 2. Kerangka pemikiran penelitian

Tabel 3. Matriks evaluasi faktor internal

\begin{tabular}{|c|c|c|c|}
\hline Faktor Internal Strategis & Bobot & Rating & Score \\
\hline \multicolumn{4}{|l|}{ Kekuatan (S) } \\
\hline Audit Internal melakukan audit Ketaatan & 0,0833 & 3 & 0,2498 \\
\hline Audit Internal telah membuat PKPT berdasarkan pedoman audit berbasis risiko & 0,1395 & 4 & 0,5579 \\
\hline $\begin{array}{l}\text { SPI mampu mengevaluasi risiko, memberikan saran perbaikan mitigasi risiko dalam } \\
\text { pengembangan risk appetite untuk pengambilan keputusan dan mampu menyusun } \\
\text { rekomendasi mitigasi risiko kritis dari temuan auditnya }\end{array}$ & 0,0833 & 4 & 0,3331 \\
\hline SPI memiliki Komponen TIM Manajemen yang integral & 0,0444 & 4 & 0,1777 \\
\hline Kemampuan koordinasi dengan pihak lain yang memberikan Saran dan Penjaminan & 0,0474 & 4 & 0,1896 \\
\hline Kepala Audit Internal melaporkan hasil audit kepada pimpinan tertinggi organisasi & 0,0773 & 4 & 0,3094 \\
\hline Audit Internal membangun Tim dan Kompetensi Auditornya & 0,0892 & 3 & 0,2676 \\
\hline Audit Internal melakukan manajemen kualaitas atas kegiatan auditnya & 0,0310 & 3 & 0,0930 \\
\hline SPI mampu memplubikasikan laporan efektivitas audit internnya ke public & 0,0280 & 3 & 0,0841 \\
\hline Total Score Tertimbang Kekuatan & 2,2623 & & \\
\hline \multicolumn{4}{|l|}{ Kelemahan (W) } \\
\hline $\begin{array}{l}\text { Audit Internal melakukan audit kinerja pada proyek-proyek infrastruktur dan } \\
\text { melakukan penilaian kinerja terhadap auditornya }\end{array}$ & 0,0833 & 2 & 0,1665 \\
\hline $\begin{array}{l}\text { Audit Internal melakukan fungsi assurance menyeluruh terhadap Tata Kelola, } \\
\text { Manajemen Risiko dan Pengendalian Internal }\end{array}$ & 0,0474 & 2 & 0,0948 \\
\hline $\begin{array}{l}\text { SPI mampu mengembangkan sendiri - revisi internal audit charter, pedoman AIBR } \\
\text { (Audit Internal Berbasis Risiko), disesuaikan dengan perubahan lingkungan bisnis. }\end{array}$ & 0,0833 & 2 & 0,1665 \\
\hline $\begin{array}{l}\text { IA melaporkan realisasi biaya, efisiensi terkait target RKAP maupun proyek, } \\
\text { melaporkan perhitungan alternatif pemilihan Sumber Daya serta melaporkan } \\
\text { peningkatan biaya akibat kurang koordinasi unsur-unsur harga pokok. }\end{array}$ & 0,0793 & 2 & 0,1586 \\
\hline Kepala Audit Intern mampu memberikan Saran dan mempengaruhi Manajemen & 0,0833 & 2 & 0,1665 \\
\hline Total Score Tertimbang Kelemahan & 0,7531 & & \\
\hline Total Score Tertimbang Faktor Internal Strategis & 3,0154 & & \\
\hline
\end{tabular}


Tabel 4. Matriks evaluasi faktor eksternal

\begin{tabular}{|c|c|c|c|}
\hline Faktor Eksternal Strategis & Bobot & Rating & Score \\
\hline \multicolumn{4}{|l|}{ Peluang (O) } \\
\hline $\begin{array}{l}\text { Perusahaan mempunyai peraturan persyaratan menjadi auditor intern, dan memiliki } \\
\text { pola karir yang jelas serta perusahaan mendorong kompetensi auditor internal }\end{array}$ & 0,1772 & 1 & 0,1772 \\
\hline $\begin{array}{l}\text { Perusahaan memfasilitasi pelatihan berkelanjutan termasuk pembekalan kemampuan } \\
\text { tata kelola, kemampuan sistem pengendalian }\end{array}$ & 0,1164 & 3 & 0,3493 \\
\hline $\begin{array}{l}\text { Direktur Utama mensuport LHA dari Manajemen Audit (Ka SPI), Direksi \& GM } \\
\text { menindaklanjuti atas laporan perkembangan temuan sementara saat pemeriksaan KAP }\end{array}$ & 0,0899 & 3 & 0,2698 \\
\hline $\begin{array}{l}\text { Keberadaan Kontrak Manajemen/KPI sebagai dasar pengukuran kinerja baik sub unit } \\
\text { dan individu. }\end{array}$ & 0,0976 & 4 & 0,3903 \\
\hline $\begin{array}{l}\text { Direktur Utama atas persetujuan Komisaris mengangkat Kepala SPI, Komitmen } \\
\text { Direktur Utama untuk memastikan kelancaran pelaksanaan tugas dan kewenangan SPI } \\
\text { yang termuat dalam Charter Audit. }\end{array}$ & 0,1772 & 4 & 0,7086 \\
\hline $\begin{array}{l}\text { Mekanisme Pendanaan termasuk peralatan kerja, infrastruktur, biaya audit, termasuk } \\
\text { pendanaan internal untuk pengembangan profesi auditor berjalan dengan baik. }\end{array}$ & 0,0536 & 3 & 0,1607 \\
\hline Total Score Tertimbang Peluang & 2,0559 & & \\
\hline \multicolumn{4}{|l|}{ Ancaman (T) } \\
\hline $\begin{array}{l}\text { Minimnya auditee meminta jasa konsultansi ke auditor dalam rangka pemberian saran } \\
\text { atau rekomendasi yang sifatnya preventif }\end{array}$ & 0,0976 & 3 & 0,2927 \\
\hline $\begin{array}{l}\text { AI tidak mendapatkan pengakuan dari Asosiasi/ Lembaga Profesi tentang kualitas } \\
\text { profesionalnya dan terdaftar sebagai anggota Asosiasi }\end{array}$ & 0,0395 & 2 & 0,0789 \\
\hline AI tidak diberikan akses penuh terhadap informasi organisasi, aset dan SDM. & 0,0976 & 3 & 0,2927 \\
\hline Manajemen tidak melakukan pengawasan terhadap kegiatan audit intern. & 0,0536 & 4 & 0,2142 \\
\hline Total Score Tertimbang Ancaman & 0,8786 & & \\
\hline Total Score Tertimbang Faktor Eksternal Strategis & 2,9345 & & \\
\hline
\end{tabular}

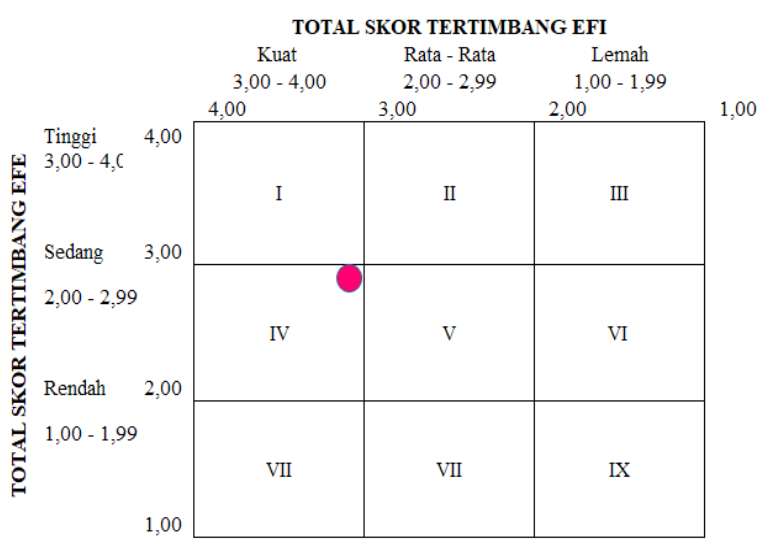

Gambar 3. Matriks Internal/Eksternal (I/E)

Nilai yang digunkan untuk sumbu horisontal berasal dari hasil matris Evaluasi Faktor Internal (EFI) sedang untuk sumbu vertical berasal dari hasil matriks Evaluasi Faktor Eksternal (EFE). Sumbu horizontal dengan nilai EFI 3,0154 menjelaskan posisi internal perusahaan yang berada pada level kuat. Sumbu vertikal dengan nilai EFE sebesar 2,9345 menunjukkan tingkat respon organisasi terhadap peluang dan ancaman yang berpengaruh sedang. Perpotongan antara sumbu horizontal dan vertical matriks akan berada pada satu dari sembilan sel dimana setiap selnya menunjukkan jenis strategi generik yang dapat dipilih. Posisi organsasi Auditor Internal (AI) Perum Jasa Tirta II terhadap pengembangan quality assurance terletak pada sel nomor IV seperti terlihat pada Gambar 3. Menurut David (2006) jika organiasi berada pada sel I, II dan IV dapat digambarkan organisasi tumbuh (grow) dan kembangkan (build) dan strategi yang dapat diambil adalah stategi intensif.

\section{Analilsi SWOT}

Matriks SWOT diperoleh dari hasil pengurangan total score tertimbang kekuatan sebesar 2,2623 dengan total score tertimbang kelemahan sebesar 0,7531 yang merupakan manivestasi dari sumbu $\mathrm{x}$ dengan nilai 1,5092 dan hasil pengurangan total score tertimbang peluang sebesar 2,0559 dengan total score tertimbang ancaman sebesar 0,8786 yang merupakan manivestasi dari sumbu y dengan nilai 1,1773 . Pertemuan antara sumbu x, y $(1,5092 ; 1,1773)$ menggambarkan titik koordinat yang menunjukkan posisi organisasi pada kuadran tertentu tertihat pada Gambar 4. 


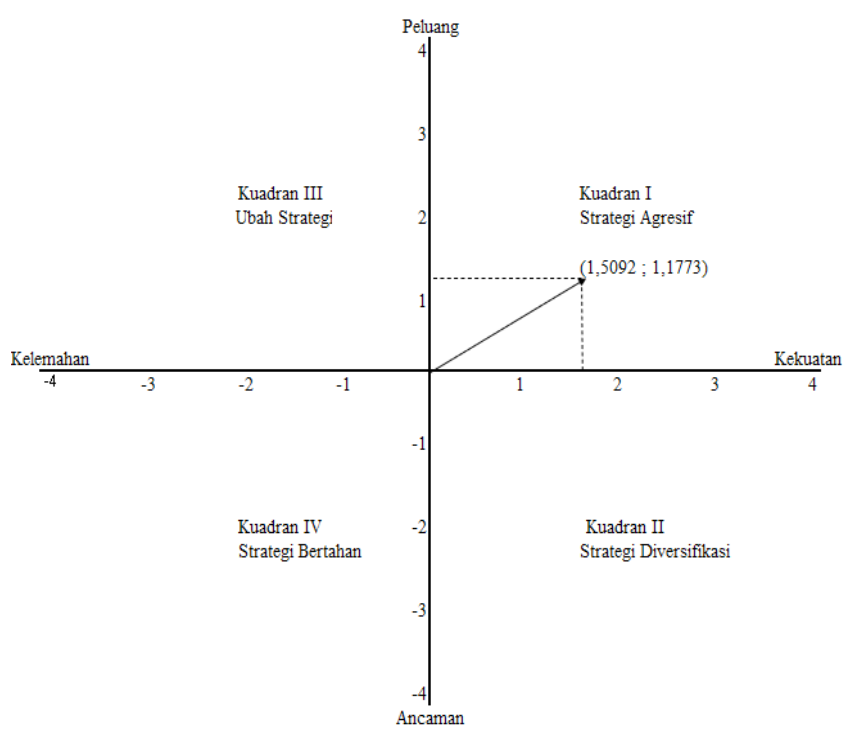

Gambar 4. Matriks SWOT

Berdasarkan Matriks SWOT posisi organisasi Auditor Internal Perum Jasa Tirta II terhadap pengembangan quality assurance pada kuadran I, menunjukkan bahwa posisi organisasi Auditor Internal yang kuat dan berpeluang, rekomendasi strategi yang diberikan adalah progresif. Artinya, organisasi dalam kondisi prima dan mantap sehingga sangat dimungkinkan untuk terus melakukan ekspansi, memperbesar pertumbuhan dan meraih kemajuan secara maksimal.

\section{Perencanaan dan Formulasi Alternatif Strategi}

Berdasarkan hasil matriks I/E yang menggambarkan kondisi organisasi pada sel IV dimana posisi organisasi tumbuh (grow) dan kembangkan (build) dan strategi yang dapat diambil adalah strategi intensif dan hasil matriks SWOT yang digambarkan posisi organisasi Auditor Internal Perum Jasa Tirta II dalam pengembangan quality assurance pada kuadran I yang berarti organisasi Auditor Internal dalam kondisi yang kuat, maka pilihan strategi alternatif yang dibangun mengarah pada mencari hubungan sebab akibat, dengan melihat posisi organiasi, sehingga dimunculkan sebab pokok dari permasalahan terindikasi. Berikut hasil hubungan sebab akibat yang tergambar dari diagram fishbone nampak pada Gambar 5. Menurut IIA (2009) dalam Internal Auditor Capability Model (IA-CM) indikator sukses kunci dalam meningkatkan startegi quality assurance SPI di PJT II dapat ditinjau menjadi 6 aspek. Dimana 6 aspek tersebut masalah yang terjadi di SPI PJT II berdasarkan pengukuran qulaity assurance tahun 2018, yaitu 1). kurang maksimalnya dalam pemberian jasa audit $(53,10 \%), 2)$. kurang maksimalnya dalam jasa lainnya $(60 \%)$ yang tercermin dari aspek peran dan layanan. 3) infrastruktur yang kurang memadai $(67,70 \%)$ yang tercermin dar aspek struktur tata kelola. 4). pemenuhan budaya kerja $(51,70 \%)$ yang tercermin dari aspek hubungan dan budaya organisasi.

Dari masalah yang ditinjau dari 6 aspek menurut IA-CM dimunculkan sebab dan akibat kemudian dimunculkan pula 3 (tiga) strategi alternatif dengan melihat kondisi organisasi pada sel IV dimana posisi organisasi tumbuh (grow) dan kembangkan (build) (hasil matriks I/E) dan posisi organisasi AI pada kuadran I (Matrisk SWOT) yang berarti organisasi Auditor Internal dalam kondisi yang kuat. 3 strategi yang dimunculkan adalah: 1). Penguatan dengan Dewan Direksi (BOD) dan Dewan Komisaris (BOC), 2). Penguatan infrastruktur dengan membangun system audit berbasis teknologi, dan 3). Fokus penguatan pada SDM yang mandiri.

\section{Penetapan Prioritas Strategi}

Penetapan prioritas strategi dilakukan melalui kuesioner kepada seluruh responden dengan penilaian bobot dilakukan dengan menggunakan metode perbandingan berpasangan (Pairwise Comparison) yang dikembangkan oleh Saaty (2005). Setiap faktor internal maupun eksternal yang dikembangkan dari elemen IA-CM diberikan bobot penilian. Dengan metode ini kemudian diolah menggunakan Analitical Networking Process (ANP). Dari masalah yang teridentifikasi dari IA-CM dengan mencari hubugan sebab akibat seperti diagram fishbone di atas dimunculkan solusi dari 3 strategi alternatif, maka dikembangkan struktur jaringan ANP untuk menentukan strategi meningkatkan quality assurance SPI PJT II, struktur jaringan ANP yang dikembangkan terlihat seperti Gambar 6. Pada tersebut menunjukkan konsesus statistik para ahli dan praktisi kaitannya dengan faktor kunci peningkatan quality assurance SPI PJT II dalam kaitannya dengan 6 aspek yang termuat dalam cluster masalah, cluster solusi dan cluster strategi.

Pada Gambar 6 dapat dilihat bahwa strategi yang merupakan prioritas tertinggi dalam peningkatatkan Quality Assurance SPI PJT II adalah fokus penguatan dukungan dari Dewan Direktur dan Dewan Komisaris sebesar 40,09\%, diikuti oleh fokus penguatan SDM yang mandiri sebesar $35,49 \%$, dan terakhir adalah penguatan infrastuktur yaitu menggunakan sistem audit yang berbasis teknologi informasi dengan nilai $26,65 \%$. Hasil kesepakatan perjanjian penilai untuk solusi 
dari sub-kriteria, solusi kriteria adalah $\mathrm{W}=0,1239$ yang berarti bahwa $12,39 \%$ responden setuju bahwa berdasarkan tingkat prioritas, strategi peningkatan Quality Assurance SPI PJT II adalah pertama fokus penguatan dukungan $\mathrm{BOD} / \mathrm{BOC}$, kedua penguatan SDM yang mandiri dan terakhir menggunakan system audit yang berbasis informasi teknologi.

\section{Implikasi Manajerial}

Penyusunan implikasi manajerial dikembangkan dari alternatif strategi yang telah dirumuskan ke dalam langkah-angkah operasional pelaksanaan strategi (strategi program) yang lebih spesifik. Penyusunan program strategi ini dilakukan dengan mempertimbangkan faktor internal dan eksternal yang telah diidentifikasi. Untuk strategi prioritas utama yaitu penguatan dukungan dari $\mathrm{BOD} / \mathrm{BOC}$ program stateginya meliputi, pengangkatan Manajer Audit/Kepala AI diangkat oleh Direktur Utama dan mendapat persetujuan Dewan Komisaris sesuai dengan PER 01/MBU-2005 tentang penerapan tata kelola perusahaan yang baik pada Badan Usaha Milik Negara. Dengan diangkatnya Kepala IA oleh Direktur
Utama mengisyaratkan bahwa manajemen berharap kepada IA bisa menjalankan perannya yaitu sebagai alat manajemen untuk memberikan masukan dan fungsi kontrol atas aktifitas yang dijalankan organisasi memalui memberikan keyakinan yang memadai bahwa apa yang dilakukan sudah benar. Langkah kedua yaitu Kepala IA yang telah dipilih harus bisa menyakinkan kepada Direktur Utama dan mampu mempengaruhi atas keputusan-keputusan dari direktur utama adalah hasil ari rekomendasi AI. Langkah ketiga Direksi dalam melakukan seleksi harus mengutamakan kompetensi. Langkah ke empat perusahaan memfasilitasi pelatihan berkelanjutan termasuk pembekalan kemampuan tata kelola, kemampuan sistem pengendalian terhadap AI.

Langkah-langkah stategi yang fokus pada penguatan SDM yang mandiri meliputi AI berupaya mendapatkan pengakuan dari Asosiasi/Lembaga Profesi tentang kualitas profesionalnya dan terdaftar sebagai anggota Asosiasi, AI dituntut mampu menjalankan perannya sesuai dengan stnadar audit, AI mampu membangun tim dan kompetensi auditornya, AI juga harus melakukan manajemen kualitas atas kegiatan auditnya, dan AI menjaga kode etik dalam bekerja.

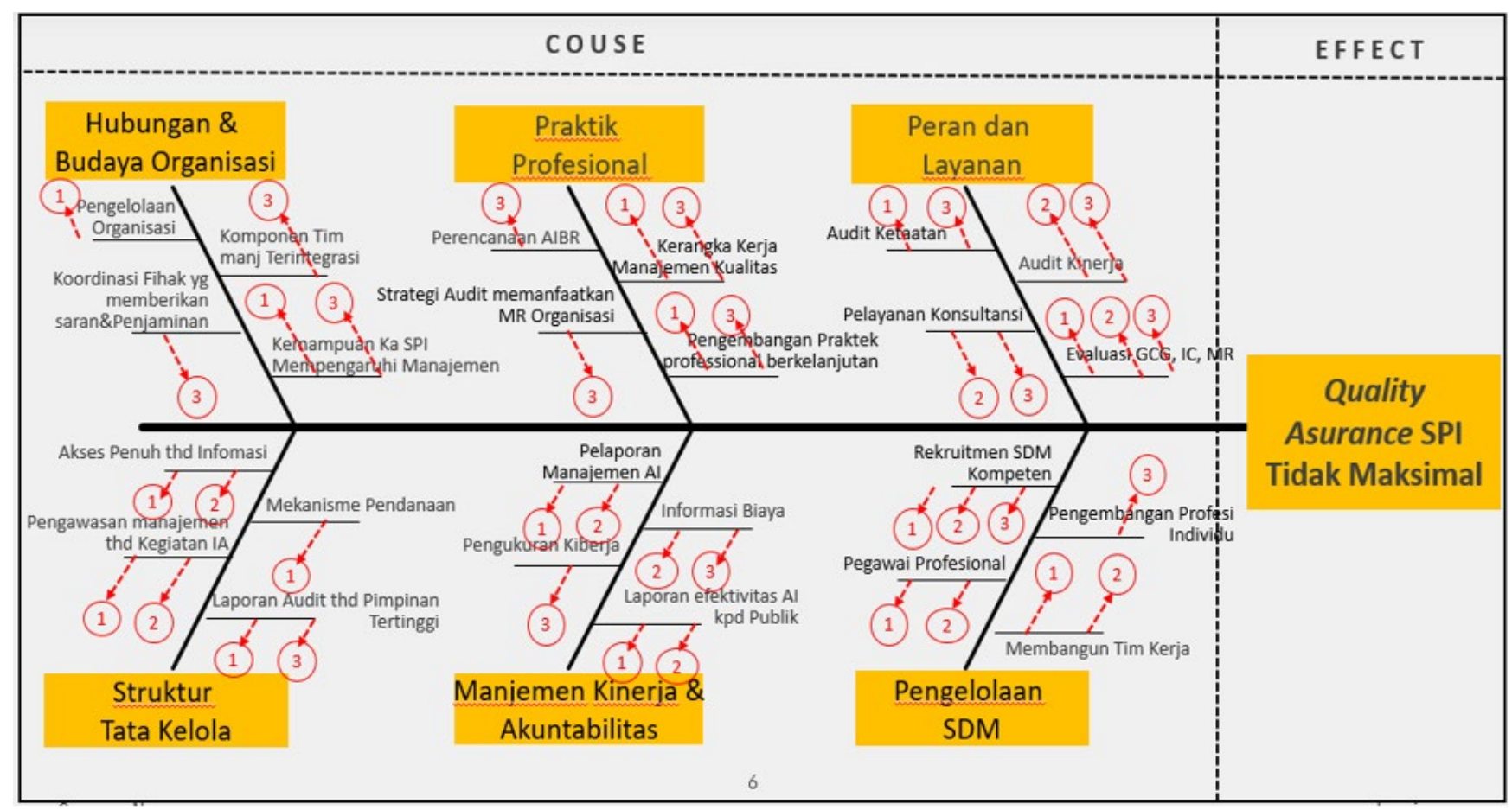

Gambar 5. Diagram fishbone 


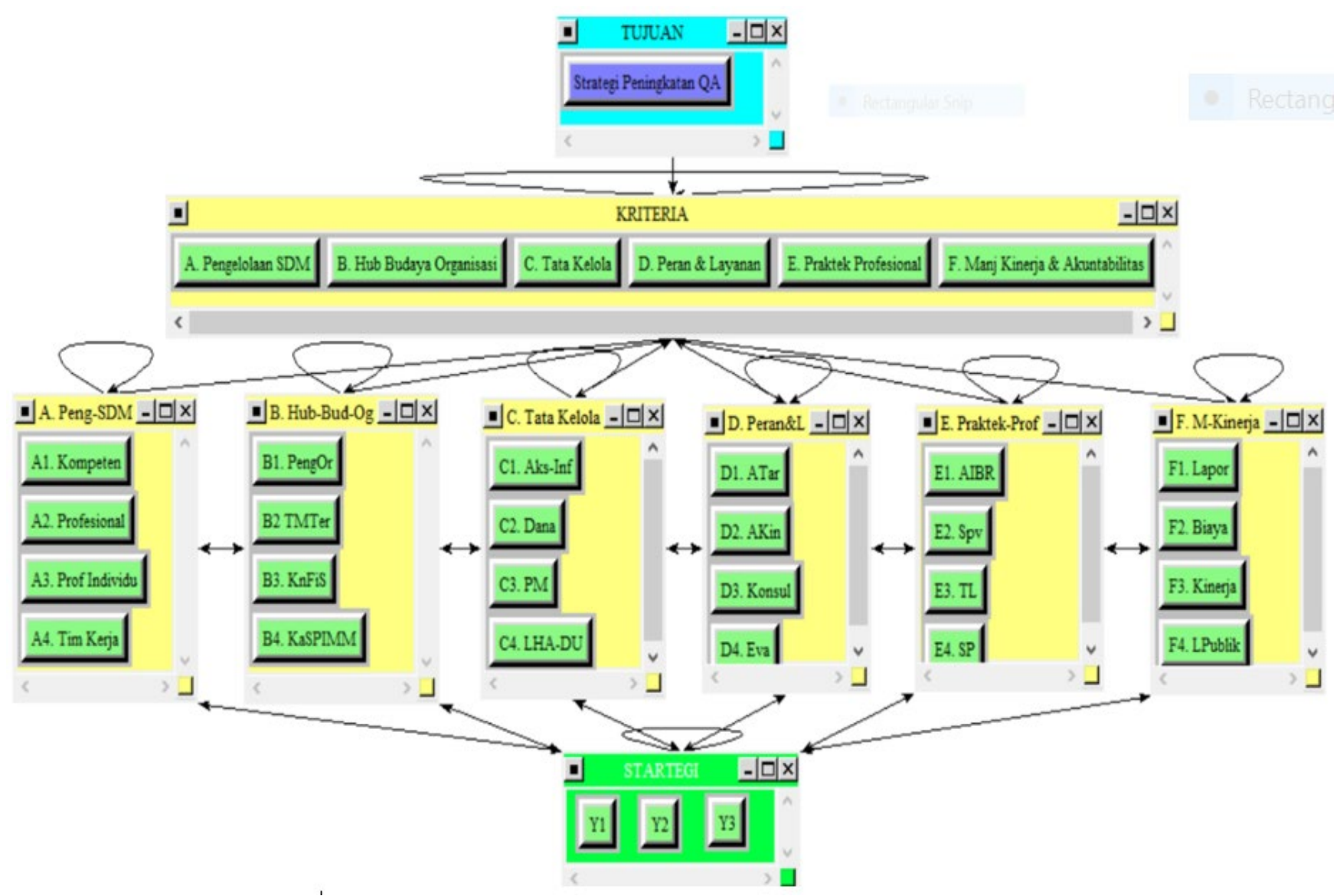

Gambar 6. Model jaringan ANP

Sehubungan dengan penguatan SDM, disarankan pula: a) pada tahap seleksi/ rekruitmen calon auditor maupun calon Kepala SPI harus melalui proses asessmen yang memadai, asesmen tersebut berdasarkan minat dan bakat calon auditor, b) terdapat pola pembinaan karier yang jelas di unit SPI dan c) Pemberian renumerasi yang lebih di unit SPI dibandingkan dengan unit-unit lain.

Untuk strategi penguatan infrastruktur dengan penguatan audit berbasis Informasi teknologi langkah yang pertama adalah AI harus mendapatkan akses tentang seluruh Informasi perusahaan dan tertuang dalam charter audit, kedua memastikan bahwa mekanisme Pendanaan termasuk peralatan kerja, infrastruktur, biaya audit, termasuk pendanaan internal untuk pengembangan profesi auditor berjalan dengan baik. Langkah ketiga dipastikan Perusahaan mempunyai peraturan persyaratan menjadi auditor intern, dan memiliki pola karir yang jelas serta perusahaan mendorong kompetensi auditor internal. Mendorong kepada divisi IT, agar terbangun IT yang terintegrasi sehingga SPI mudah dalam mengakses seluruh data Perusahaan.

\section{KESIMPULAN DAN SARAN}

\section{Kesimpulan}

Faktor-faktor yang menentukan Quality Assurance SPI PJT II dipengaruhi oleh 6 aspek, yaitu aspek Pengelolaan SDM, aspek hubungan dan budaya organisasi, aspek tata kelola, aspek peran dan layanan, aspek praktek profesional dan aspek manajemen kinerja dan akuntabilitas. Keenam aspek tersebut yang merupakan masalah tersebut terbagi menjadi solusi dalam kriteria. Dari masalah tersebut dimunculkan tiga formula alternatif strategis untuk menyusun strategi meningkatkan quality assurance audit yaitu: penguatan dukungan $\mathrm{BOD} / \mathrm{BOC}$, menerapkan sistem audit yang berbasis teknologi informasi dan fokus pada penguatan SDM. Adapun strategi yang diyakini dapat memecahkan masalah dalam peningkatan quality assurance SPIPJT II sesuai urutan prioritas yakni adalah penguatan dukungan BOD/BOC $(0,40978)$, fokus pada penguatan SDM $(0,32499)$, dan menerapkan sistem audit yang berbasis teknologi Informasi $(0,26522)$. 


\section{Saran}

Penelitian ini terbatas pada Perum Jasa Tirta II dimana perusahaan negara dengan jasa layanan publik, diharapkan untuk penelitian selanjutnya tidak terbatas pada perusahaan umum, namun bisa diterapkan pada Perseroan Terbatas (PT) atau perusahaan terbuka. Penelitian ini dengan alat ukur Internal Audit Capability Model (IA-CM), untuk penelitian selanjutnya dapat menggunakan model pengembangan lainnya.

\section{DAFTAR PUSTAKA}

[AAI] Asosiasi Auditor Internal. 2016. Standar Profesi Audit Internal. Bandung: AAI.

Abrista 2018. Elaborating cash waqf development in Indonesia using analytic network process. International Journal of Islamic Business and Economics 2(1): 1-13

Ascarya 2011. The Perssitence of Low Profit and Loss Sharing Financersistensi Margin Perbankan Konvesional dan Styariah di Indonesia. Jurnal Ekonomi dan Bisnis Islami 1(1): 1-30

[IIA] The Institute of Internal Auditors Research Foundation. 2009. Internal Audit Capability Model (IA-CM) for the Public Sector. The IIA Recearch Foundation 1(2): 1-7.
[IIA] The Institute of Internal Auditors. 2017. Definition of Internal Auditing. https://global.theiia.org/ standards-guidance/mandatory-guidance/Pages/ Definition-of-Internal-Auditing.aspx [2020 Juni 23].

Peraturan Menteri Negara Badan Usaha Milik Negara Nomor PER 01-MBU-2011 tentang Penerapan Tata Kelola Perusahaan yang Baik (Good Corporate Governance) pada Badan Usaha Milik Negara. Jakarta: Kemenbumn.

[PJT] Perum Jasa Tirta II. 2017. Laporan hasil pengukuran Penjaminan Mutu Satuan Pengawasan Intern Perum Jasa Tirta II. Purwakarta: SPI PJT II.

Rahardjo S, Gudnanto. 2011. Pengertian studi kasus menurut para ahli. https://pakarkomunikasi.com/ pengertian-studi-kasus-menurut-para-ahli [2019 Januari 21].

Saaty TL. 2005. Theory and Applications of the Analytic Network Process: Decision Making with Benefits, Opportunities, Costs and Risks. Pittsburgh: RWS Publications,

Sawyer, Lawrence B et al. 2003. Sawyer's Internal Auditing: $\left(5^{\text {th }}\right.$ ed), The Institute of Internal Auditors: Florida. 